\author{
SIF EINARSDÓTTIR, MARÍA DÓRA BJÖRNSDÓTTIR AND \\ JUKKA LERKKANEN
}

\title{
12. CROSS-CULTURAL VALIDATION OF ASSESSMENT INSTRUMENTS USED IN CAREER COUNSELLING AND GUIDANCE IN THE NORDIC COUNTRIES
}

\author{
Etic and Emic Approaches
}

\begin{abstract}
The cross-cultural application and research on assessment instruments used in career counselling and guidance in the Nordic countries is discussed. Three examples where etic and emic approaches to establish the cross-cultural validity of American instruments in Finland and Iceland are described. These are the Career Thoughts Inventory, vocational interest inventories and a measure of career adaptability. These efforts show that contextual factors influence the responses to imported measures. Emic approaches are needed to fully test the applicability of assessment instruments as well as theoretical constructs developed in other cultures, but used in career counselling in the Nordic countries.
\end{abstract}

\section{INTRODUCTION}

The Nordic countries share cultural characteristics and importance is placed on career guidance and counselling by policymakers within the welfare states. However, the countries have taken different paths both in practice and research in the field (Haug et al., 2018; Plant, 2003; Plant, Christiansen, Lovén, Vilhjálmsdóttir, \& Vuorinen, 2003). One of the most notable differences is in the use of quantitative assessment instruments. The use of assessment has been an integral part of the science and practice of career counselling and guidance influenced by the study of individual differences within psychology. In practice, instruments are used to collect information, conceptualise problems and increase self-knowledge (e.g., Hartung, 2005; Savickas, 2005a). The quality of a measure is also a key element in quantitative research. In this chapter we will first give a broad overview of the use of career-related measures in the different Nordic countries and their purpose. Second, the theoretical and methodological challenges raised by cross-cultural assessment practices are introduced. Third, examples from Nordic countries' efforts to import 
measures to capture the theoretical constructs of dysfunctional career thoughts (Sampson, Peterson, Lenz, Reardon, \& Saunders, 1996a), vocational interests (Holland, 1997), and career adaptability (Savickas, 2005b) will be given to clarify and discuss the issues raised by the application of imported measures and theories.

\section{THE USE OF ASSESSMENT INSTRUMENTS IN GUIDANCE IN THE NORDIC COUNTRIES}

Vocational psychology emerged as a scientific discipline in North America a century ago. The theories (e.g., Super, Krumboltz, Dawis, Holland, Gottfredson) were firmly based in the positivist ideology predominant at the time. Guidance practices evolved under these influences or, more specifically, within the person-environment (PE) fit paradigm (Leung, 2008; Savickas, 2005a) in the rugged individualism characterising Anglo-American industrial societies (Guichard \& Lenz, 2005; Norsworthy, Heppner, Ægisdóttir, Gerstein, \& Pedersen, 2009). The resulting career development and choice theories laid, at least partly, the foundation for practice and research in Nordic countries. For example, textbooks have been published in Nordic languages that introduce these theories to future practitioners (Højdal \& Poulsen, 2007; Onnismaa, Pasanen, \& Spangar, 2000). However, the use of assessment instruments with the accompanying focus on the individual and lack of attention to context (Whiston \& Rahardja, 2005) does not seem to have fallen on fertile ground (Plant et al., 2003). In contrast, in the Nordic welfare states, the meaning of career guidance and counselling has evolved with more focus on the context of a person's vocational life than the person alone (Plant, 2003). Nevertheless, few assessment instruments have been used in the Nordic countries and these will be reviewed here. We will start with Iceland, where their use is most apparent (Haug et al., 2018; Vilhjálmsdóttir, Chapter 10 , this volume).

The first career measure imported to Iceland, in the mid-eighties, was the Strong Interest Inventory (SII), which was translated and tested in a series of studies (Konráðs, 1990; Konráðs \& Haraldsson, 1994). Later, other interest inventories, such as the Self-Directed Search (SDS) (Holland, Powell, \& Frizsche, 1994), were translated and adapted for use with Icelandic youth (Scheving-Thorsteinsson, 2009). This emphasis on interest assessment in Iceland culminated in the development of Bendill (Einarsdóttir \& Rounds, 2007), an Icelandic interest inventory based on Holland's theory.

Other measures based on US theories have more recently been translated: for example, the Skills Confidence Inventory (SCI) (Betz, Borgen, \& Harmon, 1996), which captures self-efficacy beliefs in Holland's (1997) six broad RIASEC occupational themes. It is used to explore clients' self-efficacy in relation to their interests in line with Social Cognitive Career Theory (SCCT) (Lent, 2005; Lent, Brown, \& Hackett, 1994). Assessment instruments concerning decision-making and career adjustment have lately received increased attention. The Career Thoughts 
Inventory (CTI) (Sampson et al., 1996a) has been translated and tested, as well as a career indecision scale developed by Brown and Rector in 2008 (Abrams et al., 2013; Björnsdóttir, Kárdal, \& Einarsdóttir, 2010). Last, a measure to capture one of Savickas' (2005b) core constructs - career adaptability, from his postmodern theory of career construction - has been developed in many countries and cultures simultaneously (Savickas \& Porfeli, 2012), including Iceland (Vilhjálmsdóttir, Kjartansdóttir, Smáradóttir, \& Einarsdóttir, 2012).

In Finland, measurement tools are frequently used in guidance and counselling services offered by Employment and Economic Development Offices (TE Services) (Ministry of Economic Affairs and Employment of Finland, 2009). The Ministry of Economic Affairs and Employment of Finland (2019) has developed a web-based information and assessment system (AVO) based on Holland's (1997) theory. They currently offer an interest assessment tool and a measure of client values. The website also includes vocational and educational information. These measures are commonly used in Finnish educational institutions by career and guidance counsellors.

In Sweden and Norway, interest measures based on Holland's theory have also been available as part of information systems for public use, provided in Sweden by the employment services (n.d.) and in Norway by Norwegian Labour and Welfare Administration (NAV, 2018). Additionally, there are measures of eight values based on Schein's career anchors (Schein, n.d.), and clients can assess their own abilities related to the six RIASEC themes. People can use NAV to explore information about occupations and education based on the results of their assessment. In the occupational information system in Denmark, a circular model is applied to organise information about the labour market, but an assessment of interests or other personal qualities is not offered (Danish Ministery of Education, n.d.).

While this is not a comprehensive review of the use of assessment instruments in the Nordic countries, it is intended to provide a glimpse into which quantitative measures are used in career counselling. Career measures, especially interest inventories, seem to be most commonly used as a part of web-based assessment and information portals. Values and ability measures based on classic career theories are also used along with other more recent instruments based on emerging theories. Otherwise, the countries seem to differ in their emphasis on the use of career assessment, with Finland and Iceland differing the most from the rest. There may be two reasons why this is the case. First, the education of career counsellors in the Nordic countries is almost exclusively located within departments of education with less apparent influence of psychology (Andreassen, Einarsdóttir, Lerkkanen, Thomsen, \& Wickstrand, 2019). Second, a strong stance against the use of psychometric instruments was taken early within the field of career guidance in Denmark (Plant et al., 2003). The focus was on context in the social compensation model applied in Sweden and in Norway sociological perspectives in research have been dominant influencing practices and research traditions (Haug et al., 2018; Plant et al., 2003). 


\section{CROSS-CULTURAL APPLICATION AND VALIDATION OF ASSESSMENT INSTRUMENTS}

When instruments developed to capture theoretical constructs are imported for use in other countries, issues regarding their applicability in the new culture are raised. Within the field of cross-cultural psychology (e.g., Berry, Poortinga, Segall, \& Dasen, 2002; van de Vijver, 2015), the transfer of psychological measures has been extensively discussed and expressed in testing standards (AERA, APA, NCME, 1999; International Test Commission, 2001). Attention needs to be given to the cross-cultural validity and specificity of assessment instruments that accompany imported career theories and are traditionally used in both practice and research (Duarte \& Rossier, 2008; Watson, Duarte, \& Glavin, 2005).

When assessment instruments developed in one culture are used in another culture, questions of equivalence and bias are raised (e.g., van de Vijver \& Poortinga, 2005). Equivalence refers to whether the assessment results have the same psychological meaning and can be interpreted in the same way in the new culture as in the original one. Bias is everything that undermines the comparability or equivalence of the test results (e.g., van de Vijver, 2015). It is our contention that the heart of the matter lies in establishing the construct equivalence of a measure or, more accurately, the need to empirically test whether the instrument captures the theoretical construct (overor underrepresented) it is intended to measure in a new culture (Messick, 1989). Questions about the applicability of the theoretical constructs need to be empirically explored even if the validity of the theory has been supported in the original culture. For practical purposes, it is important to pay attention to the ecological validity of a measure within a specific social and cultural context (Duarte \& Rossier, 2008; van de Vijver \& Poortinga, 2005).

To provide a broader conceptual framework, cross-cultural psychology has made a distinction between etic and emic approaches (Berry, 1989). In short, etic approaches espouse universalism, based on the assumption that people share certain characteristics across cultures. Within this paradigm the transportation of psychological constructs, models, and measures between cultures is supported along with a cross-cultural comparison based on the positivist quantitative research tradition. The emic approach, on the other hand, is situated in the ideology of cultural relativism, which focuses on the meaning of a construct within a specific culture and supports the development of indigenous constructs, often applying qualitative approaches (see Ægisdóttir, Gerstein, Leung, Kwong-Liem, \& Lonner, 2009).

\section{THREE EXAMPLES OF CROSS-CULTURAL CAREER ASSESSMENT}

This chapter will describe importation and validity research done on a career decisionmaking scale and interest inventories in two of the Nordic countries, Finland and Iceland. Additionally, an account of recent international efforts to create a measure of career adaptability will be given. These three examples are used to clarify the process 
of cross-cultural application of theories and assessment instruments developed for career guidance. It is hoped this discussion will make the issues more concrete and allow reporting on what we have learned about the applicability of imported career theories and assessment instruments in at least two of the Nordic countries.

\section{Dysfunctional Career Thoughts}

The Career Thoughts Inventory (CTI) (Sampson et al., 1996a) is based on the Cognitive Information Processing theory (CIP) that prescribes how to think about career decisions and learn to make optimal career choices (Sampson, Reardon, Peterson, \& Lenz, 2004). The authors suggest that a screening of clients' career decision-making problems is useful to design cost-effective counselling services according to their specific needs. The CTI is a screening device and its function is to assess an individual's dysfunctional thoughts and readiness regarding career decision-making (Sampson et al., 2004). The CTI (48 items) gives a total score as well as scores from three subscales: Decision-Making Confusion (DMC), Commitment Anxiety (CA), and External Conflict (EC) (Sampson, Peterson, Lenz, Reardon, \& Saunders, 1996b). The three subscales indicate the nature of clients' dysfunctional thoughts and guide the counsellors in their choice of specific types of career interventions (Sampson et al., 2004).

In Iceland (Björnsdóttir et al., 2010), an etic approach was used to test the cross-cultural validity of the CTI. Two cross-cultural studies have also been done on the CTI in Finland (Lerkkanen, 2002, 2009). To ensure language equivalence between the original CTI and the Icelandic version, a translation method following recommended guidelines from cross-cultural psychology literature was used (Ægisdóttir, Gerstein, \& Çinarbas, 2008). In short, three independent translations of the CTI from English into Icelandic were made by three career and guidance counsellors. Then, one translation was made from the three versions and refined. Next, an Icelandic language expert reviewed the translation before it was pretested on a small focus group of undergraduate university students. Then, the Icelandic version of the CTI was back-translated into English by a native English and reviewed by the authors of the original CTI (Björnsdóttir et al., 2010). In the former Finnish study an etic approach and a similar translation process was used.

The Icelandic version of the CTI was administered to two groups of students to investigate its psychometric quality and its construct equivalence. One group consisted of Icelandic university students not seeking counselling and the second group consisted of clients seeking career counselling at a university counselling centre. The Finnish higher education data was collected by administering the CTI at the beginning of studies and after two years of studies (Lerkkanen, 2002). The general psychometric qualities of the two translated measures, Icelandic and Finnish, were evaluated and compared to the same indicators in the original instrument. This is considered an important step in the establishment of cross-cultural validity 
(e.g., AERA/APA/NCME, 1999; van de Vijver, 2015) and in line with common practices in test development. The reliability indicators of the scales were similar in the translated CTI and the original US version (see Sampson et al., 1996b) in both Finland and Iceland (see Björnsdóttir et al., 2010; Lerkkanen, 2002). In addition, the Icelandic version differentiated between clients and students (Björnsdóttir et al., 2010), thus supporting the criterion-related validity of the Icelandic version.

The expected factor solution was only partially replicated on the student data in Iceland, which indicates a lack of cross-cultural construct equivalence with the translated version (van de Vijver \& Poortinga, 2005; Ægisdóttir et al., 2008). Almost all items belonging to EC loaded high on one factor, but the items belonging to DMC and CA did not line up as expected on two separate factors (Björnsdóttir et al., 2010). This lack of structural equivalence of the DMC and CA scales shows that they do not seem to capture exactly the same constructs in Iceland as in the US. As a result, emic items might be needed to better capture the construct of dysfunctional thinking related to career decision-making in Iceland. The practical aspects of the results are that the criterion-related validity results support the use of the total score of the translated CTI in Iceland to assess the extent of dysfunctional thoughts and individual readiness to make career decisions. According to the CIP approach (Sampson et al., 1996b), this score can then be used in career counselling to estimate what type of intervention would best meet the client's needs. The two scale scores, DMC and $\mathrm{CA}$, on the other hand, cannot be used as indicators of the nature of dysfunctional thoughts and individuals' specific career-related problems or to suggest detailed counselling interventions for Icelanders (Björnsdóttir et al., 2010).

In the first Finnish study (Lerkkanen, 2002), results were in accordance with the findings of studies of students in the US. Three dimensions of dysfunctional thoughts were supported. In addition, the amount of dysfunctional thoughts was related to the students' expressed need for vocational guidance during their first two years of study. However, the amount of dysfunctional thoughts indicated by the CTI items means were lower in Finland than among comparable student samples in the US. In the second study, Lerkkanen (2009) used a more emic-contextual approach in his work with the CTI. Based on CIP theory, he developed and tested new Finnish items. The difference between the original and the new items lay in contextualising the latter within Finnish culture. The new Finnish items were phrased more accurately according to the needs of compulsory and upper-secondary education students. The items belonging to the External Conflict factor (EC) improved the most. The reliability of the new EC factor was significantly higher where an emic approach was used compared to the replicated Finnish translation of the CTI (Lerkkanen, 2002). The mean of EC among Finnish students also turned out to be higher showing that emic approaches and attention to context is important in improving the quality of the measure. 


\section{Vocational Interests}

The second example of importation and validity research concerns vocational interests. Interest inventories, most often based on Holland's (1997) RIASEC model, are traditionally used to increase self-understanding and help people to choose a job with which they are likely to be satisfied (Savickas \& Spokane, 1999). Interest assessment is commonly applied in web-based information systems to facilitate exploration of educational and vocational opportunities, as is notable in public information systems (e.g., NAV, AVO, Arbetsformedlingen) in almost all the Nordic countries. Nevertheless, not much research has been done on the crosscultural validity and applicability of these measures. Mainly etic, and recently more emic, studies have been conducted in Iceland and will be described here to show the importance of emic approaches in the cross-cultural application of imported measures and the theories they are based on.

Structural meta-analysis indicate that Holland's theory does not apply in most cultures outside US (Rounds \& Tracey, 1996), and recently in Asia (Long \& Tracey, 2006) and Africa (Morgan \& deBruin, 2017). Iceland is among the few, mainly Western countries (e.g., Germany: Nagy, Trautwein, \& Lüdtke, 2010; Serbia: Hedrich, 2008; Croatia: Šverko \& Barbarović, 2006), where the validity of Holland's theory has been supported (Einarsdóttir, Rounds, Ægisdóttir, \& Gerstein, 2002). In all these cross-cultural studies, etic approaches have been primarily applied. In spite of support for an imported theory using translated measures, an important next step in Iceland is to take an emic approach and put the theory to a more rigorous test. Thus, an indigenous pool of items (occupations or school subjects and activities) that reflects the Icelandic world of work was developed (Einarsdóttir \& Rounds, 2007).

A study of upper-secondary students based on the indigenous items indicates that a four-dimensional model better represents the structure of interests in Iceland than Prediger's (1982) and Holland's two-dimensional complementary representations (Einarsdóttir, Rounds, \& Su, 2010). Prediger's People-Things dimension was supported, but the Prestige dimension emerged second instead of Data-Ideas. Two new dimensions emerged, but their meaning and implications need further investigation (for more detail, see Einarsdóttir et al., 2010).

The dimensional results and the fact that less than half of the items can be used to develop structurally valid RIASEC scales (Einarsdóttir \& Rounds, 2007) indicate that Holland's model does not accurately describe the vocational interests of Icelanders (Einarsdóttir et al., 2010). Therefore, the indigenous item pool was extended in Iceland and administered to higher education students (Einarsdóttir \& Rounds, 2013) to start building an ecologically valid Icelandic interest model. First, the items were used to create narrow-band basic interest scales. Second, structural analysis based on the resulting 35 indigenous basic interest scales suggests that eight clusters better describe interests at the more general level. The eight interest clusters were tentatively labelled: Business and administration; Engineering and technology; 
Life-natural sciences; Manual work; Arts and humanities; Teaching and social services; Health service and protection and, finally, Services (including retail). Some, such as Business and administration, along with Arts and humanities, bear some resemblance to Holland's E and A types, respectively, but others differ (see Einarsdóttir, Eyjólfsdóttir, \& Rounds, 2013). This study shows that it is important to create indigenous measures in the Nordic countries that capture the current realities in their labour markets instead of importing aging models of vocational interests from other countries.

\section{Career Adaptability}

The third example is about the Career Adaptability Scale (CAAS 2.0), which was developed by a team of researchers from 13 countries, (Belgium, Brazil, China, France, Iceland, Italy, Korea, Netherlands, Portugal, South Africa, Switzerland, Taiwan, and the USA) to capture the construct of career adaptability (see the special issue of Journal of Vocational Behavior, 80, 2012). According to Savickas (2005b, p. 51), "career adaptability is a psychosocial construct that denotes an individual's readiness and resources for coping with current and imminent vocational developmental tasks, occupational transitions and personal trauma". The measure can be used in career interventions to assess the adaptability resources and interventions needed for individuals to tackle transitions and unexpected changes in their career.

This research program is indicative of an increased trend in psychology to perform cross-cultural studies applying mixed quantitative and qualitative methods (van de Vivjer, 2015). It reflects the simultaneous development of career assessment instruments (Tanzer, 2005) in an international context - a practice needed in a more globalised world - with increased multiculturalism within societies, and a mobile work force (Duarte \& Rossier, 2008). This is an alternative approach to the more commonly applied importation of theories and measures from one culture to another.

The first step in the development of the international measure involved a discussion of cross-cultural similarities and differences in the international team to identify universal and culture-specific aspects of the construct career adaptability. This is indicative of an emic approach, and it resulted in the definition of and joint item generation for the four self-regulation strategies reflected in the sub-dimensions of career adaptability: concern, control, curiosity, and confidence. It is notable that no culture-specific dimensions were identified at this stage, but items were also developed for the fifth dimension called co-operation but not further tested. In the second step, the resulting 100-item pool of 25 items generated for each of the four scales in the first step was reduced to 44 items in three pilot studies. In the item generation and pilot studies the reliance on English language and US samples only is more in line with etic approaches than emic. Following the pilot studies, the 44 items written in English by the international team were translated where needed and/ 
or adapted before administering them to participants in the 13 countries. An initial analysis, on the full international sample, resulted in the reduction of items to six for each scale (24 total), which comprised the final measure. The international CAAS was found to show acceptable psychometric quality and configural and metric invariance across the countries (Savickas \& Porfeli, 2012).

Iceland was one of the countries where the CAAS showed the poorest fit to the four-dimensional model of adaptability. A culturally sensitive procedure is also needed to develop a measure of career adaptability that captures the cultural nuances of the construct in each country. Thus, in Iceland a more emic study was conducted (Einarsdóttir, Vilhjálmsdóttir, Smáradóttir, \& Kjartansdóttir, 2015). Career guidance counsellors formed an expert committee to evaluate the cultural applicability of career adaptability in Icelandic culture and context. They evaluated the theoretical construct, including items generated in the international study for the measure, and discussed the possible expression of career adaptability among their clients in practice. They agreed that the five dimensions described career adaptability in the population (including co-operation). They also concluded that to fully reflect career adaptability in Iceland, two additional dimensions might be missing. Those were referred to as contribution, which is based on the importance of work as a contribution to community, and fatalism, reflecting traditional beliefs that fate may be predetermined and that things will always work out. The experts also generated indigenous items to capture these two possible facets of career adaptability and to better reflect in the Icelandic context the four original dimensions.

In short, fatalism was not supported as a separate dimension of adaptability, but contribution was. Alternative 4-6-dimensional indigenous and international models were tested in a sample of university students. All the models fell in the range of acceptable fit, but the six-dimensional model based on scales including both international and indigenous items, adding the two relational factors of cooperation and contribution, had the best fit (for more detail see Einarsdóttir et al., 2015).

\section{SUMMARY AND CONCLUSION}

A great deal is revealed about the cross-cultural validity and applicability of imported and international theories and measures of career development and choice in Nordic cultures in these three examples. They indicate that applying more emic approaches to Nordic psychometric research can cast an important light on the contextualisation of emerging and dominant theories in vocational psychology.

As the research on the cross-cultural validity of the CTI shows, the responses of Icelanders about their readiness to make career decisions only partially conform to the factor structure of the original US instrument. This was not as clearly the case in Finland. The cultural and contextual differences that exist between the US on the one hand and Finland and Iceland on the other seem to influence the responses to the CTI. When contextual (emic) items were added, the psychometric qualities of the Finnish version of the CTI improved. In regard to interest inventories, in spite of the 
presumed cross-cultural validity of the imported and adapted measures in Iceland, an emic approach indicated that Holland's US-based theory only partially describe the Icelandic vocational interest structure. This may also be the case in the other Nordic countries, where interest inventories are used in public occupational information systems. Only one Nordic country was involved in the international development of the career adaptability measure. Emic approaches within the Nordic welfare context cast new light on the evolving construct of career adaptability, indicating that important facets may be missing in the theoretical formulation and internationally developed instrument (CAAS).

The discussion here has been limited to the importation and application of quantitative assessment instruments that have historically been used in career counselling practice and research. We are fully aware of the fact that ideological currents have shifted away from the positivistic foundation of career counselling and guidance to more postmodern constructivist views and approaches (e.g., Diemer \& Gore, 2009; Hartung, 2005; McMahon, 2008). At the same time, theoretical advances in career development and choice are firmly based on the classic theories and research undertaken over the history of the field (e.g., Savickas, 2005a). Crosscultural validity, just like the construct validity of any assessment instrument, cannot be established once and for all but is a continuous process that goes hand in hand with general theory development and testing (Messick, 1989). As these examples show, it is necessary for the Nordic countries to critically evaluate the dominant theories and empirically test instruments that accompany them for use in their welfare states. The results illuminate how the context of people's vocational life, a predominant focus in the Nordic countries, influences our conceptualisations and assessment. In general, research on the cross-cultural validity of theories and measures is important for the global development of dominant and emerging theories applied in career counselling and guidance.

\section{REFERENCES}

Abrams, M. D., Ómarsdóttir, A. Ó., Björnsdóttir, M. D., Einarsdóttir, S., Martin, C., Carr, A., ... Rector, C. (2013). Measurement invariance of the career indecision profile: United States and Iceland. Journal of Career Assessment, 21(3), 469-482. doi:10.1177/1069072712475181

Ægisdóttir, S., Gerstein, L. H., \& Çinarbas, D. C. (2008). Methodological issues in cross-cultural counselling research: Equivalence, bias, and translations. The Counselling Psychologist, 36, 188-219. doi:10.1177/0011000007305384

Ægisdóttir, S., Gerstein, L. H., Leung, S. M. A., Kwong-Liem, K. K., \& Lonner, W. J. (2009). Theoretical and methodological issues when studying culture. In L. H. Gerstein, P. P. Heppner, S. Ægisdóttir, S. A. Leung, \& K. L. Norsworty (Eds.), International handbook of cross-cultural counselling: Cultural assumptions and practices worldwide (pp. 311-319). Thousand Oaks, CA: Sage Publications.

AERA/APA/NCME. (1999). Standards for educational and psychological testing. Washington, DC: American Educational Research Association.

Andreassen, I. H., Einarsdóttir, S., Lerkkanen, J., Thomsen, R., \& Wikstrand, F. (2019). Diverse histories, common ground and a shared future: The education of career guidance and counselling professionals in the Nordic countries. International Journal for Educational and Vocational Guidance, 19(3), 411-436. doi:10.1007/s10775-018-09386-9 
Arbetsformedlingen [Swedish Public Employment Services]. (n.d.). Arbetsformedlingen [Information and assessment system]. Retrieved from https://www.arbetsformedlingen.se/

AVO [Ministry of Economic Affairs and Employment of Finland]. (2019). AVO career choice programme (Information and assessment system). Retrieved from https://asiointi.mol.fi/avo/responsive/front-page

Berry, J. W. (1989). Imposed etics-emics-derived-etics: The operationalization of a compelling idea. International Journal of Psychology, 24(6), 721-735. doi:10.1080/00207598908247841

Berry, J. W., Poortinga, Y. H., Segall, M. H., \& Dasen, P. R. (2002). Cross-cultural psychology: Research and applications (2nd ed.). Cambridge: Cambridge University Press.

Betz, N. E., Borgen, F. H., \& Harmon, L. W. (1996). Skills confidence inventory applications and technical guide. Mountain View, CA: CPP, Inc.

Björnsdóttir, M. D., Kárdal, J., \& Einarsdóttir, S. (2010). An Icelandic translation and application of the career thoughts inventory: Cross-cultural considerations. The Career Planning and Adult Development Journal, 25(4), 165-167.

Brown, S. D., \& Rector, C. C. (2008). Conceptualizing and diagnosing problems in vocational decision making. In S. D. Brown \& R. W. Lent (Eds.), Handbook of counselling psychology (3rd ed., pp. 392-407). New York, NY: John Wiley \& Sons.

Danish Ministry of Education. (n.d.). UddannelsesGuiden [Assessment system]. Retrieved from https://www.ug.dk/

Diemer, M. A., \& Gore, P. A. (2009). Culture and assessment: Nomothetic and idiographic considerations. The Career Development Quarterly, 57(4), 342-347. doi:10.1002/j.2161-0045.2009.tb00120.x

Duarte, M. E., \& Rossier, J. (2008). Testing and assessment in international context: Cross- and multicultural issues. In J. A. Athanasou \& R. V. Esbroeck (Eds.), International handbook of career guidance (pp. 489-510). Dordrecht: Springer.

Einarsdóttir, S., Eyjólfsdóttir, K. Ó., \& Rounds, J. (2013). Development of indigenous basic interest scales: Re-structuring the Icelandic interest space. Journal of Vocational Behaviour, 82(2), 105-115. doi:10.1016/j.jvb.2013.01.001

Einarsdóttir, S., \& Rounds, J. (2007). Bendill, rafraen áhugakönnun: Próun og notkun [The development and use of Bendill, an Icelandic interest inventory]. Reykjavík: Háskólaútgáfan.

Einarsdóttir, S., \& Rounds, J. (2013). Bendill, rafrcen áhugakönnun: Próun og notkun [The development and use of Bendill, an Icelandic interest inventory] (2nd ed.). Reykjavík, Iceland: Námsmatsstofnun.

Einarsdóttir, S., Rounds, J., Ægisdóttir, S., \& Gerstein, L. H. (2002). The structure of vocational interests in Iceland: Examining Holland's and Gati's RIASEC models. European Journal of Psychological Assessment, 18(1), 85-95. doi:10.1027//1015-5759.18.1.85

Einarsdóttir, S., Rounds, J., \& Su, R. (2010). Holland in Iceland revisited: An emic approach to testing US interest models. Journal of Counseling Psychology, 57(3), 361-367. doi:10.1037/a0019685

Einarsdóttir, S., Vilhjálmsdóttir, G., Smáradóttir, S. B., \& Kjartansdóttir, G. B. (2015). A culture-sensitive approach in the development of the Career Adapt-Abilities Scale in Iceland: Theoretical and operational considerations. Journal of Vocational Behavior, 89, 172-181. doi:10.1016/j.jvb.2015.06.006

Guichard, J., \& Lenz, J. (2005). Career theory from international perspective. The Career Development Quarterly, 54(1), 17-28. doi:10.1002/j.2161-0045.2005.tb00137.x

Hartung, P. J. (2005). Integrated career assessment and counselling: Mindsets, models and methods. In W. B. Walsh \& M. L. Savickas (Eds.), Handbook of vocational psychology (3rd ed., pp. 371-396). Mahwah, NJ: Lawrence Erlbaum Associates.

Haug, E. H., Plant, P., Valdimarsdóttir, S., Bergom-Pruvlovic, I., Vuorinen, R., Lovén, A., \& Vilhjálmsdóttir, G. (2019). Nordic research on educational and vocational guidance: A systematic lierture review of thematic features between 2013 and 2016. International Journal for Educational and Vocational Guidance, 19(2), 13-23. doi:10.1007/s10775-018-9375-4

Hedrich, V. (2008). Structure of vocational interests in Serbia: Evaluation of the spherical model. Journal of Vocational Behavior, 73, 185-202. doi:10.1016/j.jvb.2007.12.004

Holland, J. L. (1997). Making vocational choices: A theory of vocational personalities and work environments (3rd ed.). Englewood Cliffs, NJ: Prentice-Hall.

Holland, J. L., Powell, A. B., \&, Fritzsche, B. A. (1994). The Self-Directed Search (SDS) professional user's guide, 1994 edition. Odessa, FL: Psychological Assessment Resources. 


\section{S. EINARSDÓTTIR ET AL.}

Højdal, L., \& Poulsen, L. (2007). Karrierevalg - Teorier om valg og valgprocesser. Fredensborg: Studie \& Erhverv.

International Test Commission. (2001.) International test commission guidelines for test adaption. London: Author.

Konráðs, S. (1990). Cross-cultural cross validation of the lawyer and engineer scales for linguistically equivalent forms of the strong-campbell interest inventory (Unpublished doctoral dissertation). University of Minnesota, Minneapolis, MN.

Konráðs, S., \& Haraldsson, E. (1994). The validity of using U.S. based interest norms of the strong interest inventory for Icelandic college population. Scandinavian Journal of Educational Research, $38(1), 65-76$.

Lent, R. W. (2005). A social cognitive view of career development and counselling. In S. D. Brown \& R. W. Lent (Eds.), Career development and counselling: Putting theory and research to work (pp. 101-127). Hoboken, NJ: John Wiley \& Sons.

Lent, R. W., Brown, S., \& Hackett, G. (1994). Toward a unifying social cognitive theory of career and academic interest, choice and performance. Journal of Vocational Behavior, 45(1), 79-122. doi:10.1016/j.jvb.2008.07.005

Lerkkanen, J. (2002). Koulutus- ja uravalinnan ongelmat. Koulutus- ja uravalinnan tavoitteen saavuttamista haittaavat ajatukset sekä niiden yhteys ammattikorkeakouluopintojen etenemiseen ja opiskelijoiden ohjaustarpeeseen [Educational and career choice problems: The relationship between dysfunctional educational and career thoughts, and the success of Polytechnic studies and the students' need for guidance]. Jyväskylä: Jyväskylän ammattikorkeakoulu.

Lerkkanen, J. (2009). Ohjaustarvearvio [Measure for counselling needs]. In R. Heikkinen, E. Koski, \& E. Öhman (Eds.), Futurix + Oma valintani. Keuruu, Finland: Otava.

Leung, A. S. (2008). The big five career theories. In J. A. Athanasou \& R. V. Esbroeck (Eds.), International handbook of career guidance (pp. 115-132). Dordrecht: Springer.

Long, L., \& Tracey, T. J. G. (2006). Structure of RIASEC scores in China: A structural meta-analysis. Journal of Vocational Behavior, 68(1), 39-51. doi:10.1016/j.jvb.2005.01.002

McMahon, M. (2008). Qualitative career assessment: Ahigher profile in the 21 st century? In J.A. Athanasou \& R. V. Esbroeck (Eds.), International handbook of career guidance (pp. 587-602). Dordrecht: Springer.

Messick, S. (1989). Validity. In R. L. Linn (Ed.), Educational measurement (3rd ed., pp. 13-103). New York, NY: McMillan.

Ministry of Economic Affairs and Employment of Finland. (2009). Guidance. Educational and vocational guidance in Finland. Helsinki: Lönnberg Print \& Promo. Retrieved from http://cimo.fi/instancedata/ prime_product_julkaisu/cimo/embeds/cimowwwstructure/15616_guidance_in_finland_2009.pdf

Morgan, B., \& deBruin, G. P. (2017). Structural validity of Holland's circumplex model of vocational personality types in Africa. Journal of Career Assessment, 26(2), 275-290. doi:10.1177/ 1069072717692747

Nagy, G., Trautwein, U., \& Lüdtke, O. (2010). The structure of vocational interests in Germany: Different methodologies, different conclusions. Journal of Vocational Behavior, 76(2), 153-169. doi:10.1016/ j.jvb.2007.07.002

Norsworthy, K. L., Heppner, P. P., Ægisdóttir, S., Gerstein, L. H., \& Pedersen, P. B. (2009). Exportation of U.S.-based models of counselling and counselling psychology: A critical analysis. In L. H. Gerstein, P. P. Heppner, S. Ægisdóttir, S. A. Leung, \& K. L. Norsworthy (Eds.), International handbook of cross-cultural counselling: Cultural assumptions and practices worldwide (pp. 69-88). Thousand Oaks, CA: Sage Publications.

Norwegian Labour and Welfare Administration (NAV). (2018). NAV (Information and assessment system). Retrieved from https://www.nav.no

Onnismaa, J., Pasanen, H., \& Spangar, T. (2000). Ohjaus ammattina ja tieteenalana 1. Ohjauksen lähestymistavat ja ohjaustutkimus [Counselling as a profession and science]. Porvoo, Finland: PS-Kustannus.

Plant, P. (2003). Five swans: Educational and vocational guidance in the Nordic countries. International Journal for Educational and Vocational Guidance, 3(2), 85-100. doi:10.1023/A:1024704022790 
Plant, P., Christiansen, L. L., Lovén, A., Vilhjálmsdóttir, G., \& Vuorinen, R. (2003). Research in educational and vocational guidance in the Nordic countries: Current trends. International Journal for Educational and Vocational Guidance, 3(2), 101-122. doi:10.1023/A:1024756006860.

Prediger, D. J. (1982). Dimensions underlying Holland's hexagon: Missing link between interests and occupations? Journal of Vocational Behavior, 21(3), 259-287. doi:10.1016/0001-8791(82)90036-7

Rounds, J. B., \& Tracey, T. J. (1996). Cross-cultural structural equivalence of RIASEC models and measures. Journal of Applied Psychology, 43(3), 310-329. doi:10.1037/0022-0167.43.3.310

Sampson Jr., J. P., Peterson, G. W., Lenz, J. G., Reardon, R. C., \& Saunders, D. E. (1996a). Career Thoughts Inventory (CTI). Test booklet. Odessa, FL: Psychological Assessment Resources.

Sampson Jr., J. P., Peterson, G. W., Lenz, J. G., Reardon, R. C., \& Saunders, D. E. (1996b). Career Thoughts Inventory (CTI). Professional manual. Odessa, FL: Psychological Assessment Resources.

Sampson Jr., J. P., Reardon, R. C., Peterson, G. W., \& Lenz, J. G. (2004). Career counselling and services: A cognitive information processing approach. Belmont, CA: Brooks/Cole.

Savickas, L. M. (2005a). The history of vocational psychology: Antecedents, origin and early development. In W. B. Walsh \& M. L. Savickas (Eds.), Handbook of vocational psychology (3rd ed., pp. 15-50). Mahwah, NJ: Lawrence Erlbaum.

Savickas, L. M. (2005b). The theory and practice of career construction. In S. D. Brown \& R. W. Lent (Eds.), Career development and counselling: Putting theory and research to work (pp. 42-70). Hoboken, NJ: John Wiley \& Sons.

Savickas, L. M., \& Porfeli, E. J. (2012). Career adapt-abilities scale: Construction, reliability, and measurement equivalence across 13 countries. Journal of Vocational Behavior, 80(3), 661-673. doi:10.1016/j.jvb.2012.01.011

Savickas, L. M., \& Spokane, A. R. (Eds.). (1999). Vocational interests: Meaning measurement and counselling use. Palo Alto, CA: Davis-Black.

Schein, E. H. (n.d.). Career anchors self assessment (Assessment system). Retrieved from http://www.careeranchorsonline.com

Scheving-Thorsteinsson, B. (2009). Í leit að starfi: Íslensk staðfærsla og stöðlun [Icelandic adaptation and standardization of the self-directed search]. Sálfrceðiritið, 14, 39-58.

Šverko, I., \& Barbarović, T. (2006). The validity of Holland's theory in Croatia. Journal of Career Assessment, 14, 490-507. doi:10.1177/1069072706288940

Tanzer, N. (2005). Developing tests for use in multiple languages and cultures. A plea for simultaneous development. In R. K. Hambleton, P. F. Merenda, \& C. D. Spielberger (Eds.), Adapting educational and psychological tests for cross-cultural assessment (pp. 235-263). Mahwah, NJ: Lawrence Erlbaum.

van de Vijver, F. J. R. (2015). Methodological aspects of cross-cultural research. In M. Gelfand, C. Chiu, \& Y. H (Eds.), Handbook of advances in culture and psychology (Vol. 5, pp. 101-146). New York, NY: Oxford University Press.

van de Vijver, F. J. R., \& Poortinga, Y. H. (2005). Conceptual and methodological issues in adapting tests. In R. K. Hambleton, P. F. Merenda, \& C. D. Spielberger (Eds.), Adapting educational and psychological tests for cross-cultural assessment (pp. 39-63). Mahwah, NJ: Lawrence Erlbaum.

Vilhjálmsdóttir, G., Kjartansdóttir, G. B., Smáradóttir, S. B., \& Einarsdóttir, S. (2012). Career adaptabilities scale - Icelandic form: Psychometric properties and construct validity. Journal of Vocational Behavior, 80, 698-704. doi:10.1016/j.jvb.2012.01.013

Watson, M., Duarte, M. E., \& Glavin, K. (2005). Cross-cultural perspectives on career assessment. The Career Development Quarterly, 54(1), 29-35. doi:10.1002/j.2161-0045.2005.tb00138.x

Whiston, S. C., \& Rahardja, D. (2005). Qualitative career assessment: An overview and analysis. Journal of Career Assessment, 13, 371-380. doi:10.1177/1069072705277910 